\title{
Effects of Apigenin and Astragalus Polysaccharide on the Cryopreservation of Bull Semen
}

\author{
Hongtao Wang 1,2, Ping Lu 1,2, Chongshan Yuan 1,2, Jing Zhao ${ }^{1,2}$, Hongyu Liu ${ }^{1,2}$, Wenfa Lu 1,2,3,* \\ and Jun Wang $1,2,3, *$ \\ 1 Joint Laboratory of Modern Agricultural Technology International Cooperation, Ministry of Education, \\ Jilin Agricultural University, Changchun 130118, China; hongtao2021@yeah.net (H.W.); \\ luping100419@163.com (P.L.); 18844146800@163.com (C.Y.); jlndfztd@163.com (J.Z.); \\ jlndlhy0133@163.com (H.L.) \\ 2 Key Lab of Animal Production, Product Quality and Security, Ministry of Education, \\ Jilin Agricultural University, Changchun 130118, China \\ 3 College of Animal Science and Technology, Jilin Agricultural University, Changchun 130118, China \\ * Correspondence: wenfa2004@163.com (W.L.); junwang2004@126.com (J.W.); Tel.: +86-0431-84532936 (W.L.); \\ Fax: +86-0431-84532936 (W.L.)
}

check for

updates

Citation: Wang, H.; Lu, P.; Yuan, C.; Zhao, J.; Liu, H.; Lu, W.; Wang, J. Effects of Apigenin and Astragalus Polysaccharide on the Cryopreservation of Bull Semen. Animals 2021, 11, 1506. https:// doi.org/10.3390/ani11061506

Academic Editor: Fiammetta Berlinguer

Received: 19 April 2021

Accepted: 20 May 2021

Published: 22 May 2021

Publisher's Note: MDPI stays neutral with regard to jurisdictional claims in published maps and institutional affiliations.

Copyright: (c) 2021 by the authors. Licensee MDPI, Basel, Switzerland. This article is an open access article distributed under the terms and conditions of the Creative Commons Attribution (CC BY) license (https:/ / creativecommons.org/licenses/by/ $4.0 /)$.
Simple Summary: Oxidative stress in mammalian sperm can be induced during cryopreservation; therefore, it is important to inhibit oxidative stress to maintain sperm motility during cryopreservation. The present study was performed to investigate the effects of supplementing apigenin (AP), astragalus polysaccharide (APS), or their combination on an extender for bull semen freezing. Sperm viability, motility, and motion parameters; acrosome integrity and membrane integrity; endogenous antioxidant indices; and reactive oxygen species (ROS) and malondialdehyde (MDA) levels were evaluated after semen thawing. Our results indicated that $0.2 \mathrm{mmol} / \mathrm{L} \mathrm{AP}$ or $0.5 \mathrm{mg} / \mathrm{mL}$ APS improved the cryopreservation of bull sperm; moreover, their combination in the extender could further improve the protective effects on bull sperm post-thaw.

Abstract: The purpose of this study was to determine the effects of apigenin and astragalus polysaccharides on the cryopreservation of bovine semen. Apigenin, astragalus polysaccharides, or their combination were added to a frozen diluent of bovine semen. Afterwards, Computer Assisted Semen Analysis (CASA), membrane functionality, acrosome integrity, mitochondrial integrity, CAT, SOD, GSH-Px, MDA, and ROS detection were conducted. The results showed that adding $0.2 \mathrm{mmol} / \mathrm{L}$ $\mathrm{AP}$ or $0.5 \mathrm{mg} / \mathrm{mL}$ APS could improve the quality of frozen sperm. Compared to $0.2 \mathrm{mmol} / \mathrm{L} \mathrm{AP}$ alone, the combination of $0.2 \mathrm{mmol} / \mathrm{L} \mathrm{AP}$ and $0.3 \mathrm{mg} / \mathrm{mL}$ APS significantly increased the total motility (TM), average path distance (DAP), straight line distance (DSL), average path velocity (VAP), curvilinear velocity (VCL), wobble (WOB), and sperm CAT and SOD levels $(p<0.05)$, while reducing the ROS and MDA levels $(p<0.05)$. These results indicated that the addition of $0.2 \mathrm{mmol} / \mathrm{L} \mathrm{AP}$ or $0.5 \mathrm{mg} / \mathrm{mL}$ APS alone has a protective effect on the freezing of bovine semen. Compared to the addition of $0.2 \mathrm{mmol} / \mathrm{L} \mathrm{AP}$, a combination of $0.2 \mathrm{mmol} / \mathrm{L} \mathrm{AP}$ and $0.3 \mathrm{mg} / \mathrm{mL}$ APS could further improve the quality of frozen semen.

Keywords: apigenin; astragalus polysaccharide; bull semen; cryopreservation

\section{Introduction}

Artificial insemination (AI) accounts for an increasing proportion of cattle reproduction [1]. The development of AI involves increasingly stringent requirements on the quality of frozen semen [2]. Although the quality of semen after thawing has improved in the past few decades, about $50 \%$ of sperm are fixed or destroyed due to freezing and thawing, resulting in a reduced fertilization ability [3]. The oxidative stress caused by the production of reactive oxygen species (ROS) during the freezing and thawing process was found to be 
the main reason for the decreased semen motility after thawing. As mammalian sperms lack part of the cytoplasm, their antioxidant capacity is not sufficient to resist the lipid peroxidation (LPO) caused by the ROS-induced polyunsaturated fatty acids that are bound to sperm phospholipids [4]. Due to the antioxidant enzymes in semen, such as glutathione peroxidase (GSH-Px), catalase (CAT), and superoxide dismutase (SOD), concentrations are very important. As a mammalian sperm cytoplasm has a relatively high concentration of polyunsaturated fatty acids (PUFA), it lacks sufficient natural antioxidant reserves. Therefore, the addition of natural antioxidants to the frozen semen dilution has become necessary to improve sperm motility after thawing. Antioxidants can balance ROS and reduce $\mathrm{LPO}$ levels to improve the freezing resistance of semen and improve the quality of melted semen. Antioxidants have been widely used in frozen semen [4-6]. Plant-derived compounds are considered to be important sources of antioxidants because they produce almost no side effects and are easily available in nature [7].

Flavonoids are widely present in nature. These compounds act as free radical scavengers and antioxidants, and have antimutagenic, anti-inflammatory, and antiviral effects [8-11]. Apigenin (AP) (APEBIO Co., Ltd., Houston, Texas, USA), a flavonoid, is widely distributed in a plant [10]. Compared to that of other structurally related flavonoids, it has a lower inherent toxicity to normal cells $[12,13]$. AP penetrates cells and binds to DNA to form an apigenin-DNA complex, protecting the DNA from oxidative stress in the cell [14]. Recent studies have demonstrated that adding AP to a frozen diluent of swine semen could increase sperm motility and the antioxidant enzyme content and reduce the concentration of the LPO product malondialdehyde after thawing [2]. Astragalus polysaccharide (APS) (Shanghai Yuanye Biological Co., Ltd., Shanghai, China) can be considered as an antioxidant as there is research that shows that APS can inhibit mitochondrial damage by scavenging ROS [15]. Recent studies have found that APS could reduce the oxidative damage of cardiomyocytes caused by free radicals and lipid peroxides as well as reduce membrane damage. Furthermore, APSs have recently been found to have antibacterial and antiviral properties and can be used as immune enhancers [16]. Due to the various properties of APS, it can be used for the cryopreservation of pig semen, and studies have shown that it can improve semen vitality and antioxidant levels [17].

Different antioxidants have a synergistic effect on the removal of active oxygen $[18,19]$. $\mathrm{AP}$ and APS, as two different antioxidants, have been shown to improve semen quality through different action pathways and action times $[17,20]$. However, neither of the two substances have been used before in the freezing of bovine semen. The purpose of this study was to explore the effects of AP, APS, and their combination on the freezing of bovine semen.

\section{Materials and Methods}

\subsection{Experimental Design}

In this study, pooled semen was extended using a Tris extender with different levels of $\operatorname{AP}(0,0.2,0.4,0.6$, and $0.8 \mathrm{mmol} / \mathrm{L})$ and $\operatorname{APS}(0,0.1,0.3,0.5$, and $0.7 \mathrm{mg} / \mathrm{mL})$ or a combination of AP and APS $(0.2 \mathrm{mmol} / \mathrm{L} \mathrm{AP}, 0.2 \mathrm{mmol} / \mathrm{L}+0.1 \mathrm{mg} / \mathrm{mL}, 0.2 \mathrm{mmol} / \mathrm{L}+$ $0.3 \mathrm{mg} / \mathrm{mL}, 0.2 \mathrm{mmol} / \mathrm{L}+0.5 \mathrm{mg} / \mathrm{mL}$, and $0.2 \mathrm{mmol} / \mathrm{L}+0.7 \mathrm{mg} / \mathrm{mL}$ ). Each experiment was repeated at least three times.

\subsection{Animals}

This study was conducted at Jilin Agricultural University in P.R. China. Experimental Animal Welfare and Ethics Committee of Jilin Agricultural University approval was gained, the number is 20200803001. Four bulls ( 4 years old) were used for semen collection. The uniformity of the feed, housing, and light conditions were ensured. The bull feed was composed of $45 \%$ corn, $32 \%$ soybean cake, $5 \%$ wheat bran, $5 \%$ rice bran meal, $6 \%$ soybean germ meal, $2 \%$ molasses, and $5 \%$ bull special premix. In terms of nutritional indicators, the bull feed had approximately $20 \%$ crude protein, $13 \%$ moisture, $7 \%$ crude ash, $0.6-0.7 \%$ calcium, $0.6-0.7 \%$ total phosphorus, and $0.8-1 \%$ sodium chloride. The bulls had free access to water and salt, and no additional antioxidants were present in the feed. 


\subsection{Bull Semen Collection}

Semen samples were collected using an artificial vagina twice a week per bull, for 12 weeks. The criteria for cryopreservation were as follows: the semen samples were sent to the laboratory within $30 \mathrm{~m}$. The semen was held in a water bath at $37^{\circ} \mathrm{C}$ while the sperm concentration was estimated using a calibrated spectrophotometer and the motility of sperm was subjectively evaluated using microscopy, at a concentration of at least $1 \times 10^{9}$ spermatozoa $/ \mathrm{mL}$, a sperm motility $\geq 70 \%$, and an abnormality $\leq 15 \%$. Healthy ejaculates were used in the experiments. After the initial assessment, the semen samples were mixed to eliminate individual differences.

\subsection{Basic Extender}

The basic extender was slightly modified from that described by Tarig et al. [21], as shown in Table 1. All of the chemicals were placed into a capacity bottle and double evaporative water was used to stabilize the capacity to $100 \mathrm{~mL}$, a magnetic stirrer was used to stir for $2 \mathrm{~h}$, then $20 \%$ egg yolk and 3\% glycerin were added and stirred again for two hours to completely dissolve. The basic diluent was divided evenly and AP or APS of different concentrations were added.

Table 1. Composition of the basic hand-made extender.

\begin{tabular}{cc}
\hline Ingredient & Dosage \\
\hline Glucose & $1.1 \mathrm{~g}$ \\
Citric acid & $1.48 \mathrm{~g}$ \\
Tris & $2.42 \mathrm{~g}$ \\
Penicillin sodium & $0.06 \mathrm{~g}$ \\
Streptomycin sulfate & $0.1 \mathrm{~g}$ \\
Egg yolk & $20 \%$ \\
Glycerin & $3 \%$ \\
\hline
\end{tabular}

\subsection{Semen Processing}

After the quality evaluation, the samples were diluted and incubated in a water bath at $37^{\circ} \mathrm{C}$ for $30 \mathrm{~min}$ for the full absorption of AP and APS by the sperm membrane. After that, the samples were packed in $0.25 \mathrm{~mL}$ straws (IMV Co., Ltd, L'Aigle, Paris, France) with $8 \times 10^{6}$ sperm/straws, then cooled from $37^{\circ} \mathrm{C}$ to $4{ }^{\circ} \mathrm{C}$ for $2 \mathrm{~h}$, as previously described, and subsequently cooled from $4{ }^{\circ} \mathrm{C}$ to $-140{ }^{\circ} \mathrm{C}$ for approximately $8 \mathrm{~min}$, using a turbo freezer (Minitube Co., Ltd, Munich, Bavaria, Germany). After that, the straws were transferred to a liquid nitrogen tank $\left(-196^{\circ} \mathrm{C}\right)$ and stored for 1 month before detection.

\subsection{Evaluation of Post-Thawed Sperm}

\subsubsection{Computer Assisted Semen Analysis}

The kinematic parameters of sperm were analyzed using a sperm analyzer (developed jointly by Hamilton and IMV, IVOS II, 10871, 6 October 2017). Two straws were thawed by immersion in a water bath at $37^{\circ} \mathrm{C}$ for $30 \mathrm{~s}$. Each sample was analyzed at least three times. Five microliters were detected for each straw, and four fields were randomly examined. The total motility (TM), average path velocity (VPA), straight line velocity (VSL), curvilinear velocity (VCL), amplitude of lateral head displacement (ALH), beat/cross frequency (BCF), straightness (STR), linearity (LIN), wobble (WOB), distance of average path (DAP), straight line distance (DSL), and curvilinear distance (DCL) were recorded.

\subsubsection{Acrosome Integrity}

The sperm acrosome integrity was slightly modified from that described by Masoudi et al. [22]. The sample was centrifuged, and the resultant sperm pellet was obtained. It was then equilibrated in $96 \%$ ethanol for $10 \mathrm{~min}$. Afterwards, the sperm was placed on a glass slide and fluorescein isothiocyanate-conjugated pea lectin (PSA-FITC) (sigma) was added. The slides were incubated for $20 \mathrm{~m}$, and glycerol was added to fix the 
sperm onto the slide. At least 5 fields of view were observed through a fluorescence microscope (400× magnification) (Cytation 5 imaging reader, Bio Tek Co., Ltd, Winusky, Vermont, USA). The percentage of sperm with abnormal acrosomes was recorded by counting a total of 200 sperm under visualized microscopically. (see Figure 1).

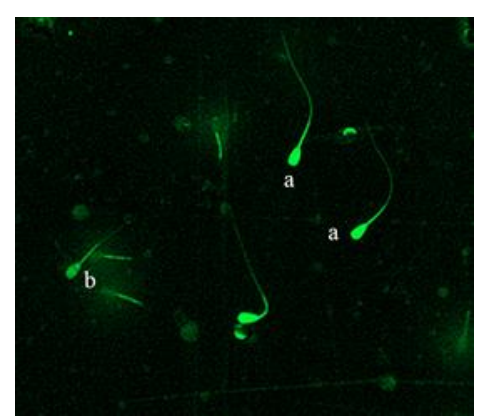

Figure 1. After fluorescent staining with FITC-PSA, live sperms were marked by green fluorescence (a) and dead sperms were marked by light green (b).

\subsubsection{Plasma Membrane Integrity}

The method of measuring sperm plasma membrane integrity used was slightly modified according to the method in an article published by R.A. Harrison et al. [23]. Using the double staining method of carboxy fluorescein diacetate (CFDA) (Andy Forno BiotechnologyCo., Ltd. Wuhan, China) and propidium iodide (PI) (Coolaber), $0.46 \mathrm{mg}$ of CFDA was dissolved in $1 \mathrm{~mL}$ of dimethyl sulfoxide and $0.5 \mathrm{mg}$ of PI was dissolved in $1 \mathrm{~mL}$ of normal saline. It was stored at $-20{ }^{\circ} \mathrm{C}$ and protected from light. Afterwards, $20 \mu \mathrm{L}$ of CFDA and $10 \mu \mathrm{L}$ of PI were dissolved in $1 \mathrm{~mL}$ of PBS with a $\mathrm{pH}$ of 7.4 and $0.01 \mathrm{~mol} / \mathrm{L}$. A 20-microliter semen sample was then taken and an 80-microliter staining solution was added. The cells were incubated at $37^{\circ} \mathrm{C}$ for $10 \mathrm{~min}$ and washed with PBS. After washing, a 10-microliter sample and was taken and at least 5 fields of view were observed through a fluorescence microscope (400× magnification) (Cytation 5 imaging reader, Bio Tek Co., Ltd, Winusky, Vermont, USA). The percentage of sperm with abnormal acrosomes was recorded by counting a total of 200 sperm under visualized microscopically. (see Figure 2).

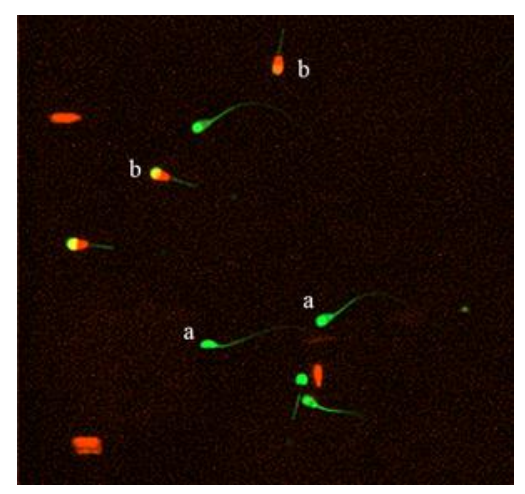

Figure 2. After double fluorescent staining with CFDA/PI, live sperms were marked by green heads (a) and dead sperms were marked by red heads (b).

\subsubsection{Mitochondrial Activity}

The method of measuring sperm mitochondrial activity was slightly modified according to the method in an article published by Shahverdi et al. [24]. The mitochondrial activity of sperm was evaluated using double fluorescent staining with rhodamine 123 (Rh123) (Coolaber) and PI. Rh123 was dissolved with Me2SO and stored in the dark, while PI was dissolved in a physiological saline. The semen was then mixed with Rh123 and PI, incubated for $20 \mathrm{~min}$, taken out and centrifuged to remove the supernatant, and then was added to PBS to mix the semen. Afterwards, the sample was centrifuged again to wash 
away the impurities and at least 5 fields of view were observed through a fluorescence microscope (400× magnification) (Cytation 5 imaging reader, Bio Tek Co., Ltd, Winusky, Vermont, USA). The percentage of sperm with abnormal acrosomes was recorded by counting a total of 200 sperm under visualized microscopically. (see Figure 3).

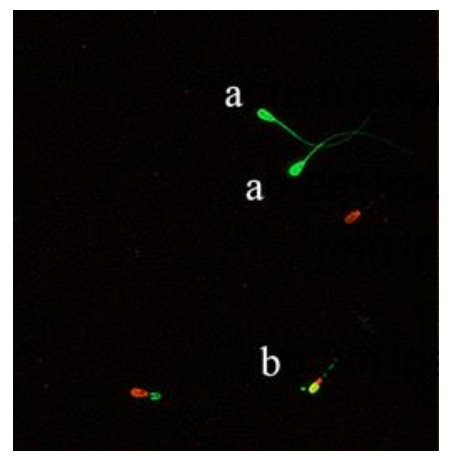

Figure 3. After double fluorescent staining with Rh123/PI, live sperms were marked by green heads (a) and dead sperms were marked by red heads (b).

\subsubsection{Endogenous Antioxidant Indices Detection in the Frozen-Thawed Semen}

The determination of various endogenous antioxidant enzymes (superoxide dismutase, glutathione peroxidase, and catalase) was carried out using an enzyme-linked immunoassay kit (Shanghai Enzyme Biotechnology Co., Ltd., China), according to the manufacturer's instructions. The sample to be tested was mixed with a sample diluent. After incubation, the enzyme-labeling reagent and stop solution were added in sequence. The resulting mixture was then placed into a microplate reader for analysis.

\subsubsection{MDA and ROS Concentration Determination in Post-Thawed Semen}

A bull MDA and ROS ELISA assay kit was used to determine the concentrations of MDA and ROS (Shanghai Enzyme Biotechnology Co. Ltd., China). The bovine semen was centrifuged repeatedly to destroy the sperm's structure. Next, $40 \mu \mathrm{L}$ of diluent was added to the sample, and placed onto a shaker to mix the semen and diluent thoroughly. It was then incubated in a $37^{\circ} \mathrm{C}$ incubator for $30 \mathrm{~min}$, washed with a washing solution 5 times, $50 \mu \mathrm{L}$ of enzyme-labeled reagent was added, incubated again in a $37^{\circ} \mathrm{C}$ incubator for $30 \mathrm{~min}$, and washed 5 times after equilibration. Two kinds of diluent shake were then added and mixed well. The entire procedure was performed for $10 \mathrm{~min}$ at $37^{\circ} \mathrm{C}$ in the dark. After adding the stop solution, the absorbance was measured using a microplate reader at a wavelength of $450 \mathrm{~nm}$, and the content of MDA and ROS was calculated according to the standard curve.

\subsection{Statistical Analyses}

All results were expressed as mean \pm SEM. The mean values of the sperm characteristics, movement characteristics, GSH-Px, CAT, SOD, ROS, and MDA concentrations, acrosome integrity, mitochondrial activity, and membrane integrity were compared using Statistical Product and Service Solutions (SPSS 22.0; SPSS, Chicago, IL, USA) Duncan's multiple range test by ANOVA procedure; $p<0.05$ was considered statistically significant.

\section{Result}

3.1. Effect of Different Concentrations of AP and APS on Several Kinematic Parameters of Bovine Semen Samples after Thawing

3.1.1. Effect of Different Concentrations of AP on Several Kinematic Parameters of Frozen Bovine Semen

The results are shown in Table 2. Adding different concentrations of AP could improve the kinematic parameters of frozen semen. A concentration of $0.2 \mathrm{mmol} / \mathrm{L}$ significantly improved the kinematic ability of the TM, DAP, DSL, VAP, VSL, LIN, and WOB $(p<0.05)$. Simultaneously, $0.2 \mathrm{mmol} / \mathrm{L}$ AP relieved the DCL and VCL levels $(p<0.05)$. Although 
adding $0.4 \mathrm{mmol} / \mathrm{L} \mathrm{AP}$ also had a certain effect, it was not as good as the state of the sperm when $0.2 \mathrm{mmol} / \mathrm{L}$ was added.

Table 2. A computer-aided sperm analysis of the kinematic parameters of frozen-thawed bull sperm after an AP addition.

\begin{tabular}{|c|c|c|c|c|c|}
\hline & Control & $0.2 \mathrm{mmol} / \mathrm{L}$ & $0.4 \mathrm{mmol} / \mathrm{L}$ & $0.6 \mathrm{mmol} / \mathrm{L}$ & $0.8 \mathrm{mmol} / \mathrm{L}$ \\
\hline $\mathrm{TM}(\%)$ & $37.30 \pm 2.09^{b}$ & $43.25 \pm 1.66^{\mathrm{a}}$ & $41.43 \pm 3.27^{a b}$ & $41.30 \pm 2.09 \mathrm{ab}$ & $38.43 \pm 2.23^{b}$ \\
\hline $\mathrm{DAP}(\mu \mathrm{m})$ & $7.70 \pm 1.19^{c}$ & $11.04 \pm 1.28^{\mathrm{a}}$ & $10.52 \pm 1.57^{\mathrm{ab}}$ & $9.80 \pm 1.10 \mathrm{abc}$ & $8.38 \pm 1.08^{b c}$ \\
\hline $\operatorname{DSL}(\mu \mathrm{m})$ & $5.75 \pm 1.04^{b}$ & $9.00 \pm 1.23^{\mathrm{a}}$ & $8.95 \pm 0.72^{\mathrm{a}}$ & $7.28 \pm 1.39^{a b}$ & $7.03 \pm 1.40^{a b}$ \\
\hline $\operatorname{DCL}(\mu \mathrm{m})$ & $21.62 \pm 1.57^{\mathrm{a}}$ & $18.16 \pm 1.26^{b}$ & $19.41 \pm 0.84^{\mathrm{ab}}$ & $20.63 \pm 1.36^{\mathrm{ab}}$ & $20.52 \pm 1.60^{a b}$ \\
\hline $\operatorname{VAP}(\mu \mathrm{m} / \mathrm{s})$ & $28.23 \pm 2.17^{b}$ & $32.69 \pm 1.11^{\mathrm{a}}$ & $32.61 \pm 1.58^{a}$ & $32.00 \pm 1.50^{\mathrm{a}}$ & $30.59 \pm 1.60 \mathrm{ab}$ \\
\hline $\operatorname{VSL}(\mu \mathrm{m} / \mathrm{s})$ & $21.57 \pm 1.52^{b}$ & $24.81 \pm 1.04^{\mathrm{a}}$ & $25.18 \pm 1.41^{\mathrm{a}}$ & $24.27 \pm 0.89^{\mathrm{a}}$ & $21.90 \pm 1.00^{b}$ \\
\hline $\operatorname{VCL}(\mu \mathrm{m} / \mathrm{s})$ & $70.03 \pm 2.78^{a}$ & $63.97 \pm 2.28^{b}$ & $64.99 \pm 2.98^{b}$ & $65.06 \pm 1.45^{\mathrm{b}}$ & $65.08 \pm 1.29^{b}$ \\
\hline STR(VSL/VAP) (\%) & $76.99 \pm 8.67$ & $76.04 \pm 4.95$ & $77.49 \pm 7.03$ & $76.07 \pm 5.42$ & $71.77 \pm 5.01$ \\
\hline LIN (VSL/VCL) (\%) & $30.94 \pm 3.48^{c}$ & $38.04 \pm 1.45^{\mathrm{ab}}$ & $38.86 \pm 3.19^{a}$ & $37.32 \pm 1.73^{\mathrm{ab}}$ & $33.66 \pm 1.62 b c$ \\
\hline WOB(VAP/VCL) (\%) & $40.37 \pm 3.43^{b}$ & $51.19 \pm 3.00^{\mathrm{a}}$ & $50.27 \pm 3.19^{a}$ & $49.24 \pm 3.20^{\mathrm{a}}$ & $47.06 \pm 3.29^{a}$ \\
\hline $\mathrm{ALH}(\mu \mathrm{m})$ & $3.84 \pm 0.03^{b}$ & $4.02 \pm 0.04^{\mathrm{a}}$ & $3.78 \pm 0.13^{b}$ & $3.73 \pm 0.11^{b}$ & $3.82 \pm 0.10^{b}$ \\
\hline $\mathrm{BCF}(\mathrm{hz})$ & $10.00 \pm 0.62$ & $10.56 \pm 0.77$ & $10.11 \pm 1.06$ & $10.44 \pm 1.22$ & $9.91 \pm 0.93$ \\
\hline
\end{tabular}

Abbreviations: Mean \pm SEM of the total motility (TM), average path distance (DAP), straight line distance (DSL), curve distance (DCL), average path velocity (VAP), straight line velocity (VSL), curvilinear velocity (VCL), straightness (STR), linearity (LIN), wobble (WOB), amplitude of lateral head displacement (ALH), and beat/cross frequency (BCF). The different superscripted letters ( $a, b, c)$ across the rows represent significant differences $(p<0.05)$.

\subsubsection{Effect of Different Concentrations of APS on Several Kinematic Parameters of Frozen} Bovine Semen

The results are shown in Table 3. Adding different concentrations of APS improved the kinematic parameters of semen freezing. When the concentration was $0.5 \mathrm{mg} / \mathrm{mL}$, the sperm's TM, DAP, DSL, VAP, VSL, LIN, WOB levels were significantly increased, and the DCL and VCL levels were simultaneously relieved $(p<0.05)$. Although the addition of 0.5 and $0.7 \mathrm{mg} / \mathrm{mL}$ APS was also significantly different from the control group in some kinematic parameters $(p<0.05)$, generally, the best effect was achieved when $0.5 \mathrm{mg} / \mathrm{mL}$ APS was added.

Table 3. A computer-aided sperm analysis of the kinematic parameters of frozen-thawed bull sperm after an APS addition.

\begin{tabular}{|c|c|c|c|c|c|}
\hline & Control & $0.1 \mathrm{mg} / \mathrm{mL}$ & $0.3 \mathrm{mg} / \mathrm{mL}$ & $0.5 \mathrm{mg} / \mathrm{mL}$ & $0.7 \mathrm{mg} / \mathrm{mL}$ \\
\hline TM (\%) & $35.50 \pm 1.98^{c}$ & $37.24 \pm 1.02^{b c}$ & $39.41 \pm 1.87^{a b}$ & $40.89 \pm 1.10^{a}$ & $38.22 \pm 1.37 \mathrm{abc}$ \\
\hline $\mathrm{DAP}(\mu \mathrm{m})$ & $8.41 \pm 0.79^{b}$ & $10.27 \pm 1.07^{a b}$ & $10.78 \pm 1.15^{\mathrm{a}}$ & $11.45 \pm 1.60^{\mathrm{a}}$ & $11.10 \pm 1.24^{\mathrm{a}}$ \\
\hline DSL $(\mu \mathrm{m})$ & $7.27 \pm 1.39^{c}$ & $9.02 \pm 1.14^{b c}$ & $9.72 \pm 1.00 \mathrm{ab}$ & $11.32 \pm 0.88^{a}$ & $10.75 \pm 1.52^{\mathrm{ab}}$ \\
\hline $\mathrm{DCL}(\mu \mathrm{m})$ & $23.47 \pm 0.77^{\mathrm{a}}$ & $22.12 \pm 1.02 \mathrm{ab}$ & $20.52 \pm 1.35 \mathrm{bc}$ & $19.85 \pm 1.29^{c}$ & $21.50 \pm 1.28^{a b c}$ \\
\hline $\operatorname{VAP}(\mu \mathrm{m} / \mathrm{s})$ & $31.83 \pm 1.38^{b}$ & $34.45 \pm 2.46^{\mathrm{ab}}$ & $34.67 \pm 1.28^{\mathrm{ab}}$ & $36.15 \pm 1.56^{\mathrm{a}}$ & $34.63 \pm 1.51 \mathrm{ab}$ \\
\hline $\operatorname{VSL}(\mu \mathrm{m} / \mathrm{s})$ & $23.39 \pm 1.44^{b}$ & $25.98 \pm 1.45^{\mathrm{a}}$ & $27.12 \pm 1.16^{\mathrm{a}}$ & $28.10 \pm 1.55^{\mathrm{a}}$ & $26.46 \pm 1.18^{a}$ \\
\hline $\operatorname{VCL}(\mu \mathrm{m} / \mathrm{s})$ & $68.45 \pm 1.76^{\mathrm{a}}$ & $64.38 \pm 1.54^{b}$ & $64.04 \pm 1.98^{b}$ & $63.51 \pm 2.26^{b}$ & $63.51 \pm 2.10^{b}$ \\
\hline STR (VSL/VAP) (\%) & $73.54 \pm 4.30$ & $75.13 \pm 6.17$ & $78.94 \pm 3.38$ & $77.73 \pm 2.64$ & $76.49 \pm 3.30$ \\
\hline LIN (VSL/VCL) (\%) & $34.24 \pm 3.00^{b}$ & $40.64 \pm 3.02^{a}$ & $42.16 \pm 2.31^{a}$ & $44.35 \pm 3.62^{\mathrm{a}}$ & $41.72 \pm 2.45^{\mathrm{a}}$ \\
\hline WOB (VAP/VCL) (\%) & $46.53 \pm 2.38^{b}$ & $53.52 \pm 3.76^{\mathrm{a}}$ & $54.18 \pm 2.33^{a}$ & $56.99 \pm 3.07^{\mathrm{a}}$ & $54.54 \pm 2.06^{\mathrm{a}}$ \\
\hline ALH $(\mu \mathrm{m})$ & $3.65 \pm 0.17$ & $3.55 \pm 0.11$ & $3.64 \pm 0.14$ & $3.67 \pm 0.27$ & $3.46 \pm 0.19$ \\
\hline $\mathrm{BCF}(\mathrm{hz})$ & $11.11 \pm 1.07$ & $10.89 \pm 0.70$ & $11.18 \pm 1.28$ & $11.29 \pm 1.29$ & $11.23 \pm 0.77$ \\
\hline
\end{tabular}

Abbreviations: Mean \pm SEM of the total motility (TM), average path distance (DAP), straight line distance (DSL), curve distance (DCL), average path velocity (VAP), straight line velocity (VSL), curvilinear velocity (VCL), straightness (STR), linearity (LIN), wobble (WOB), amplitude of lateral head displacement (ALH), and beat/cross frequency (BCF). The different superscripted letters (a, b, c) across the rows represent significant differences $(p<0.05)$. 


\subsection{Effects of AP and APS at Different Concentrations on Sperm Plasma Membrane Integrity,} Acrosome Integrity, and Mitochondria Activity after Thawing

3.2.1. Effects of AP at Different Concentrations on Sperm Plasma Membrane Integrity, Acrosome Integrity, and Mitochondria Activity

The results of plasma membrane, acrosome integrity, and mitochondria activity assays following a supplementation with $0,0.2,0.4,0.6$, and $0.8 \mathrm{mmol} / \mathrm{L} \mathrm{AP}$ are summarized in Figure 4 . The mitochondria activity was significantly higher in the $0.2 \mathrm{mmol} / \mathrm{L}$ group $(p<0.05)$, and both the plasma membrane and the acrosome integrity were also improved in the AP $0.2 \mathrm{mmol} / \mathrm{L}(p<0.05)$ group, when compared to the others.

A

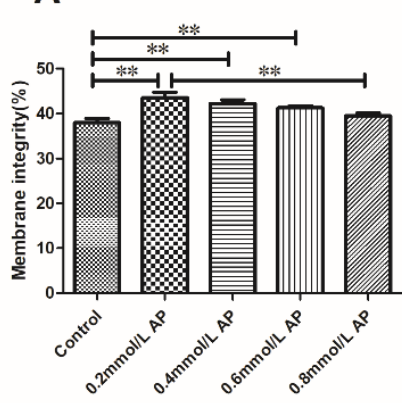

B

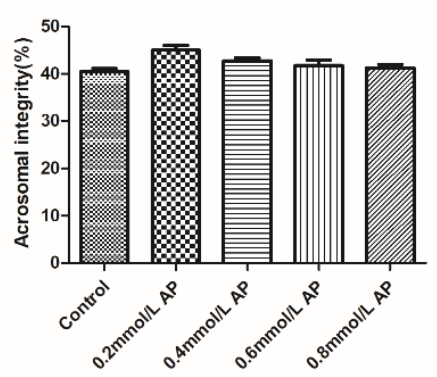

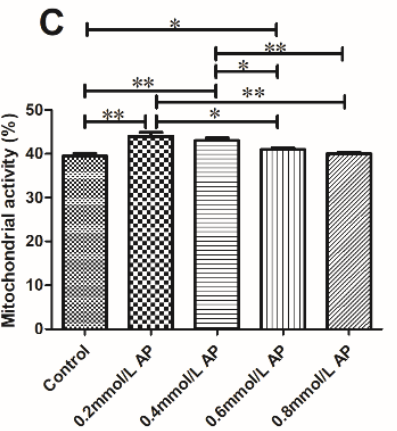

Figure 4. Effect of different concentrations of AP on the integrity of the plasma membrane (A), acrosome (B), and mitochondria $(C)$ after the thawing of bovine semen. The different asterisks represent significant differences among the groups $\left({ }^{*} p<0.05 ;{ }^{* *} p<0.01\right)$.

3.2.2. Effects of APS at Different Concentrations on Sperm Plasma Membrane Integrity, Acrosome Integrity, and Mitochondria Activity

The results of plasma membrane, acrosome integrity, and mitochondria activity assays following a supplementation with $0,0.1,0.3,0.5$, and $0.7 \mathrm{mg} / \mathrm{mL}$ APS are summarized in Figure 5. The mitochondria activity, plasma membrane, and acrosome integrity were significantly higher in the $0.5 \mathrm{mg} / \mathrm{mL}$ group $(p<0.05)$.

A

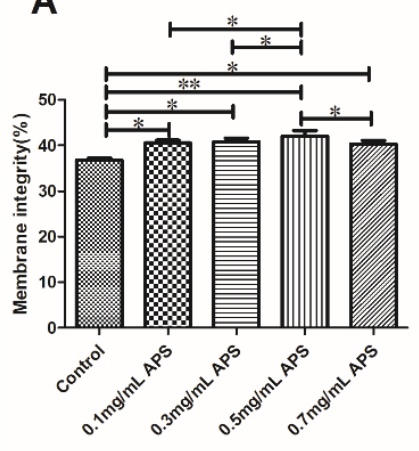

B

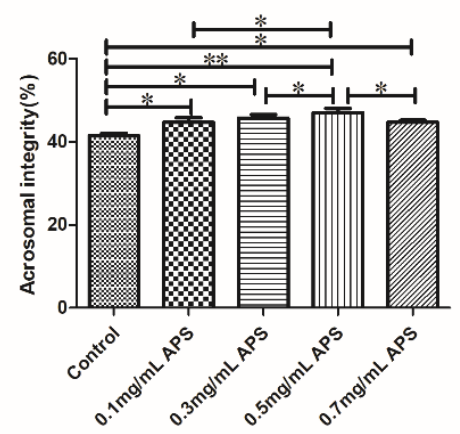

C

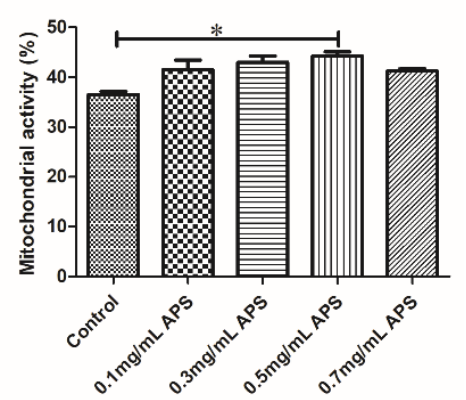

Figure 5. Effect of different concentrations of APS on the integrity of the plasma membrane (A), acrosome (B), and mitochondria $(C)$ after the thawing of bovine semen. The different asterisks represent significant differences among the groups $\left({ }^{*} p<0.05 ; * * p 0.01\right)$.

\subsection{Antioxidant Enzymes, ROS, and MDA Content in Semen after Thawing}

3.3.1. Effect of AP on the Antioxidant Enzyme Level in Sperm

The results of the CAT, GSH-Px, and SOD assays after semen cryopreservation in 0, $0.2,0.4,0.6$, and $0.8 \mathrm{mmol} / \mathrm{L} \mathrm{AP}$ are shown in Figure 6. The CAT, GSH-Px, and SOD levels in the AP $0.2 \mathrm{mmol} / \mathrm{L}$ groups retained better activity $(p<0.05)$ than the other groups. 
A

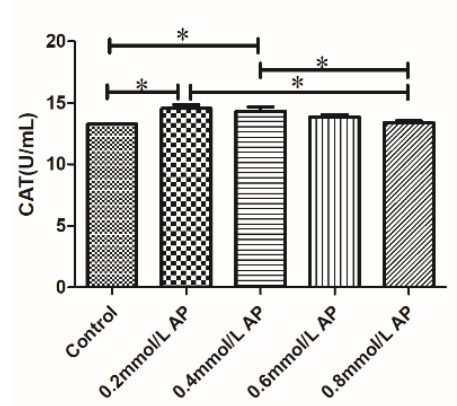

B

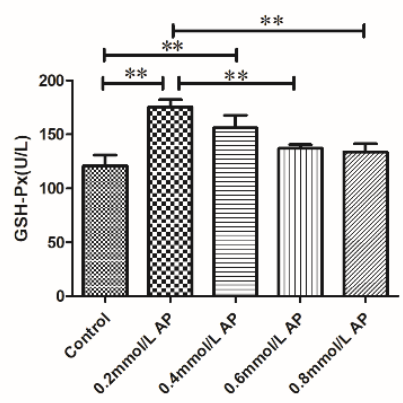

C

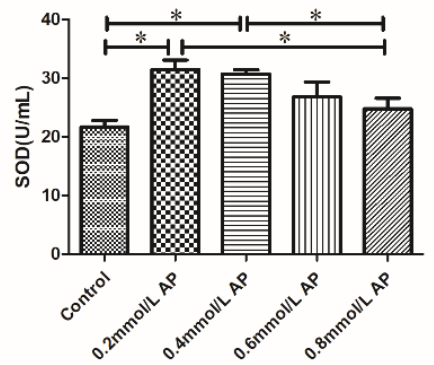

Figure 6. Effect of different concentrations of AP on the antioxidant enzyme activity in bull semen after thawing (A-C). The different asterisks represent significant differences among the groups $\left({ }^{*} p<0.05 ;{ }^{* *} p<0.01\right)$.

\subsubsection{Effects of APS on the Antioxidant Enzyme Level in Sperm}

The results of the CAT, GSH-Px, and SOD assays after semen cryopreservation in 0, 0.1, $0.3,0.5$, and $0.7 \mathrm{mg} / \mathrm{mL}$ APS are depicted in Figure 7. The CAT, GSH-Px, and SOD levels in the APS $0.5 \mathrm{mg} / \mathrm{mL}$ group were higher $(p<0.05)$ than those in the other treatment groups.
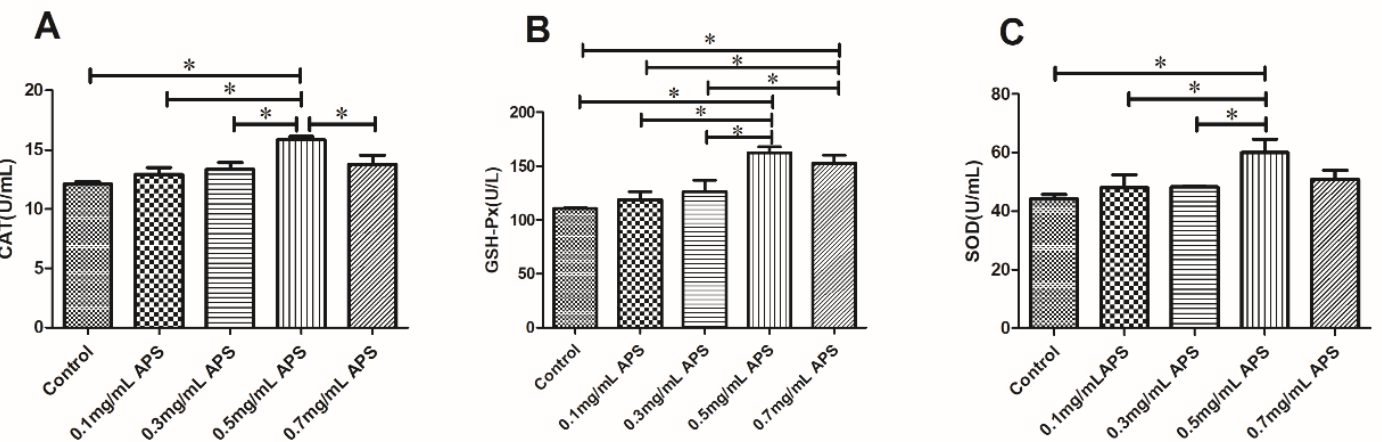

Figure 7. Effect of different concentrations of APS on the antioxidant enzyme activity in bull semen after thawing (A-C). The different asterisks represent significant differences among the groups $\left({ }^{*} p<0.05 ;{ }^{*} p<0.01\right)$.

3.3.3. Effects of the Addition of Different Concentrations of AP on the Oxidation Products of Bovine Semen

The results of the ROS and MDA assays after sperm cryopreservation in 0, 0.2, 0.4, 0.6, and $0.8 \mathrm{mmol} / \mathrm{L} \mathrm{AP}$ are shown in Figure 8 . The ROS level was significantly reduced in the AP $0.2 \mathrm{mmol} / \mathrm{L}$ group $(p<0.05)$ compared to that in the others, and this group also demonstrated a significant reduction in MDA levels $(p<0.05)$.
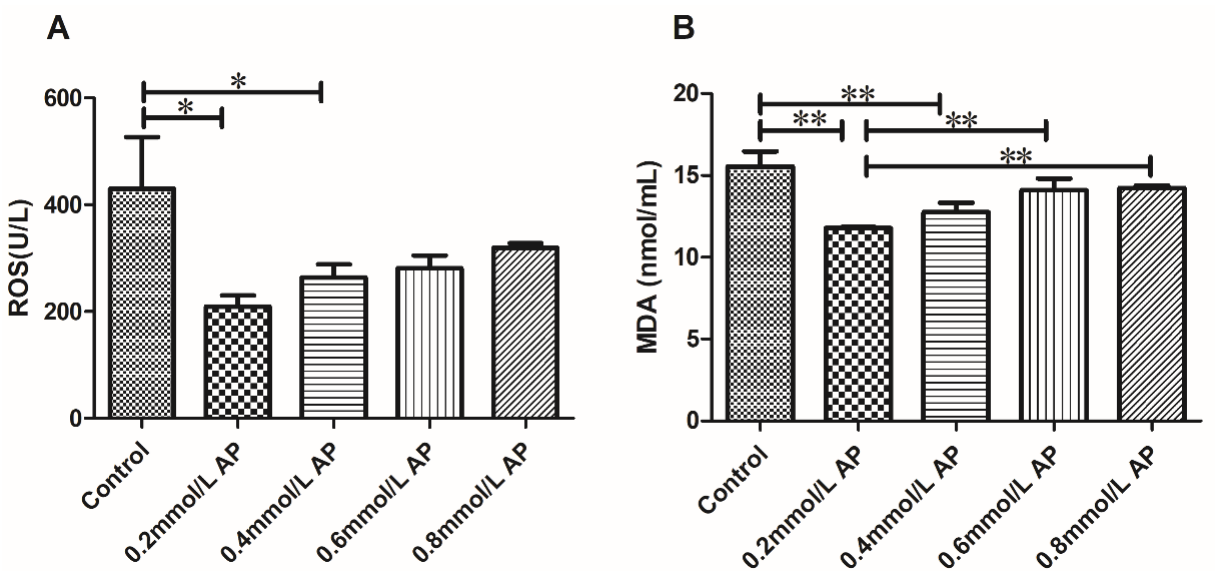

Figure 8. Effect of different concentrations of AP on the oxidation products of cattle semen after thawing $(\mathbf{A}, \mathbf{B})$. Different asterisk represents significant differences among the groups $\left({ }^{*} p<0.05 ;{ }^{* *} p<0.01\right)$. 
3.3.4. Effects of the Addition of Different Concentrations of APS on Oxidation Products of Bovine Semen

The results of the ROS and MDA assays in sperm samples cryopreserved in 0, 0.1, 0.3, 0.5 , or $0.7 \mathrm{mg} / \mathrm{mL}$ APS are shown in Figure 9. Both the ROS and MDA levels were reduced in the APS $0.5 \mathrm{mg} / \mathrm{mL}$ groups compared to those in the others $(p<0.05)$.
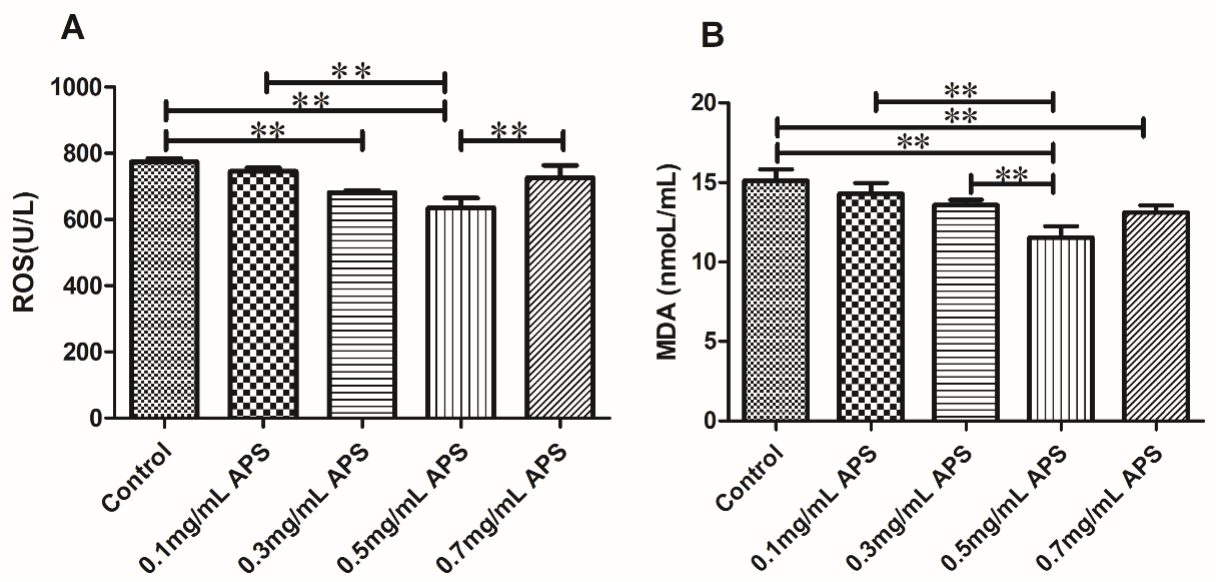

Figure 9. Effect of different concentrations of APS on the oxidation products of cattle semen after thawing $(\mathbf{A}, \mathbf{B})$. The different asterisks represent significant differences among the groups $(* * p<0.01)$.

\subsection{Effect of the Combined Use of AP and APS on Several Kinematic Parameters of Bovine Semen Samples after Thawing}

Effects of AP and APS on the Kinematic Parameters of Frozen Bovine Semen

The results are shown in Table 4 . A combined addition further improved the kinematic parameters of frozen semen compared to that with $0.2 \mathrm{mmol} / \mathrm{L} \mathrm{AP}$ alone. A combination of $0.2 \mathrm{mmol} / \mathrm{L}$ AP and $0.3 \mathrm{mg} / \mathrm{mL}$ APS significantly improved the TM, DAP, DSL, VAP, and WOB kinematic abilities. It also simultaneously relieved the VCL level $(p<0.05)$.

Table 4. A computer-aided sperm analysis of the kinematic parameters of frozen-thawed bull sperm after a combined AP and APS addition $(\mathrm{mmol} / \mathrm{L}+\mathrm{mg} / \mathrm{mL})$.

\begin{tabular}{|c|c|c|c|c|c|}
\hline & $0.2 \mathrm{AP}$ & $0.2 \mathrm{AP}+0.1 \mathrm{APS}$ & $0.2 \mathrm{AP}+0.3 \mathrm{APS}$ & $0.2 \mathrm{AP}+0.5 \mathrm{APS}$ & $0.2 \mathrm{AP}+0.7 \mathrm{APS}$ \\
\hline TM (\%) & $39.75 \pm 1.15^{b}$ & $42.54 \pm 1.42^{a}$ & $43.21 \pm 1.41^{\mathrm{a}}$ & $41.79 \pm 1.10^{\mathrm{ab}}$ & $39.52 \pm 1.16^{\mathrm{b}}$ \\
\hline $\mathrm{DAP}(\mu \mathrm{m})$ & $10.31 \pm 0.99^{c}$ & $12.55 \pm 0.84^{\mathrm{ab}}$ & $12.91 \pm 0.98^{\mathrm{a}}$ & $12.10 \pm 1.16^{\mathrm{ab}}$ & $10.88 \pm 0.83^{b c}$ \\
\hline $\mathrm{DSL}(\mu \mathrm{m})$ & $10.15 \pm 1.11^{b}$ & $12.22 \pm 0.99^{a}$ & $12.79 \pm 1.11^{\mathrm{a}}$ & $11.14 \pm 0.96^{\mathrm{ab}}$ & $11.00 \pm 1.05^{\mathrm{ab}}$ \\
\hline $\mathrm{DCL}(\mu \mathrm{m})$ & $22.89 \pm 1.67$ & $22.15 \pm 1.46$ & $20.85 \pm 1.85$ & $22.45 \pm 1.56$ & $21.07 \pm 2.18$ \\
\hline $\operatorname{VAP}(\mu \mathrm{m} / \mathrm{s})$ & $33.50 \pm 1.63^{b}$ & $35.97 \pm 1.21^{\mathrm{a}}$ & $36.75 \pm 0.97^{\mathrm{a}}$ & $34.91 \pm 0.91 \mathrm{ab}$ & $33.64 \pm 1.18^{b}$ \\
\hline $\operatorname{VSL}(\mu \mathrm{m} / \mathrm{s})$ & $26.71 \pm 0.78^{b}$ & $28.14 \pm 1.15^{\mathrm{ab}}$ & $29.26 \pm 1.18^{a}$ & $27.24 \pm 0.93^{\mathrm{ab}}$ & $26.48 \pm 2.01^{b}$ \\
\hline $\operatorname{VCL}(\mu \mathrm{m} / \mathrm{s})$ & $66.99 \pm 2.83$ & $66.59 \pm 2.38$ & $65.30 \pm 2.35$ & $66.45 \pm 2.37$ & $65.69 \pm 2.60$ \\
\hline STR(VSL/VAP) (\%) & $80.02 \pm 5.89$ & $78.31 \pm 3.91$ & $79.64 \pm 3.69$ & $78.12 \pm 4.00$ & $78.92 \pm 7.78$ \\
\hline LIN (VSL/VCL) (\%) & $39.97 \pm 2.45$ & $42.34 \pm 2.74$ & $44.82 \pm 1.55$ & $41.03 \pm 1.52$ & $40.47 \pm 4.53$ \\
\hline WOB(VAP/VCL) $(\%)$ & $50.01 \pm 1.37^{\mathrm{c}}$ & $54.04 \pm 1.45^{\mathrm{ab}}$ & $56.32 \pm 1.10^{\mathrm{a}}$ & $52.58 \pm 1.94^{b c}$ & $51.30 \pm 2.94^{b c}$ \\
\hline $\mathrm{ALH}(\mu \mathrm{m})$ & $3.46 \pm 0.27$ & $3.34 \pm 0.13$ & $3.46 \pm 0.28$ & $3.39 \pm 0.20$ & $3.26 \pm 0.11$ \\
\hline $\mathrm{BCF}(\mathrm{hz})$ & $10.35 \pm 1.12$ & $10.69 \pm 0.91$ & $10.68 \pm 0.99$ & $10.62 \pm 0.93$ & $10.29 \pm 1.26$ \\
\hline
\end{tabular}

Abbreviations: Mean \pm SEM of the total motility (TM), average path distance (DAP), straight line distance (DSL), curve distance (DCL), average path velocity (VAP), straight line velocity (VSL), curvilinear velocity (VCL), straightness (STR), linearity (LIN), wobble (WOB), amplitude of lateral head displacement (ALH), and beat/cross frequency (BCF). The different superscripted letters (a, b, c) across the rows represent significant differences $(p<0.05)$. 
3.5. Effects of the Combined Use of AP and APS on Sperm Plasma Membrane Integrity, Acrosome Integrity, and Mitochondria Activity after Thawing

Effect of the Combined Use of AP and APS on Plasma Membrane Integrity, Acrosome Integrity, and Mitochondria Activity

A combined AP and APS treatment further improved the mitochondria activity, sperm plasma membrane integrity, and acrosome integrity in frozen semen compared to an addition of $0.2 \mathrm{mmol} / \mathrm{L} \mathrm{AP}$ alone (Figure 10). A combination of $0.2 \mathrm{mmol} / \mathrm{L} \mathrm{AP}$ and $0.3 \mathrm{mg} / \mathrm{mL}$ APS significantly improved the mitochondria activity, sperm plasma membrane integrity, and acrosome integrity of the semen $(p<0.05)$.

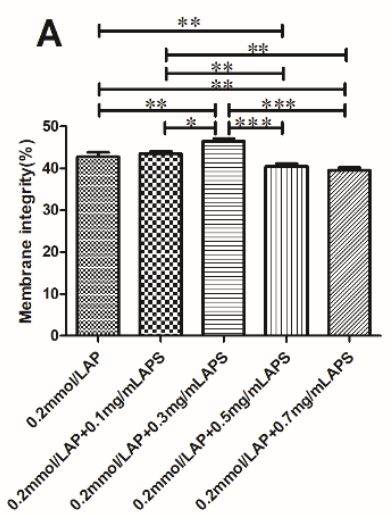

B

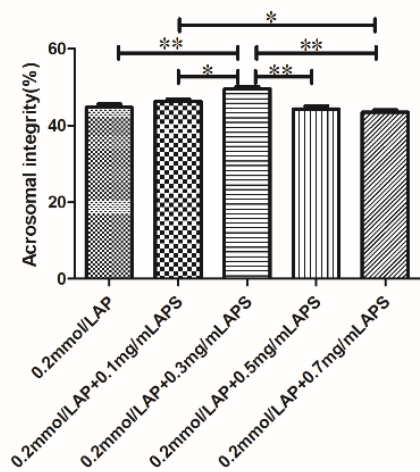

C

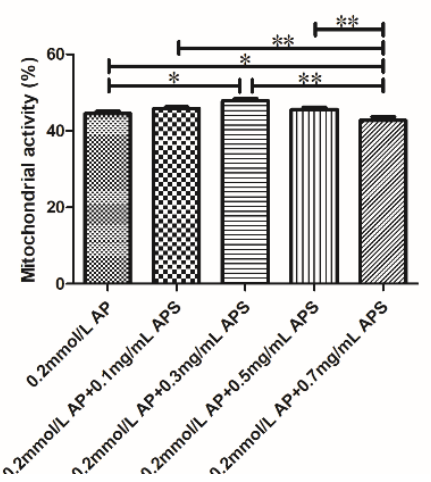

Figure 10. Effect of the combined use of AP and APS on the plasma membrane, acrosome, and mitochondria of bovine semen $(\mathbf{A}, \mathbf{B}, \mathbf{C})$. The different asterisks represent significant differences among the groups $\left({ }^{*} p<0.05 ;{ }^{* *} p<0.01 ;{ }^{* * *} p<0.001\right)$.

\subsection{Antioxidant Enzymes, ROS, and MDA Content in Semen after Thawing}

3.6.1. Effects of the Combined Use of AP and APS on Antioxidant Enzymes in Sperm

Combined supplementation resulted in a further improvement in the CAT, GSH-Px, and SOD activity in frozen semen when compared to $0.2 \mathrm{mmol} / \mathrm{L} \mathrm{AP}$ supplementation alone (Figure 11). A combination of $0.2 \mathrm{mmol} / \mathrm{L} \mathrm{AP}$ and $0.3 \mathrm{mg} / \mathrm{mL}$ APS significantly improved the SOD and CAT activity in these samples $(p<0.05)$.

A

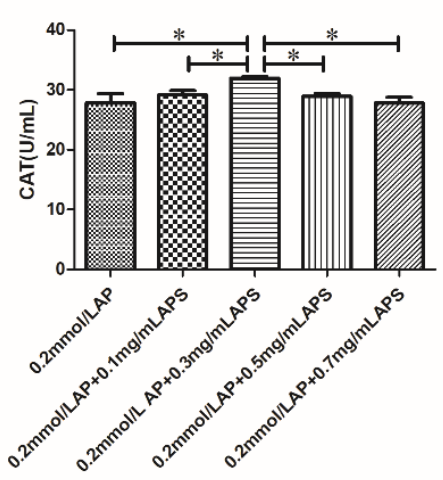

B

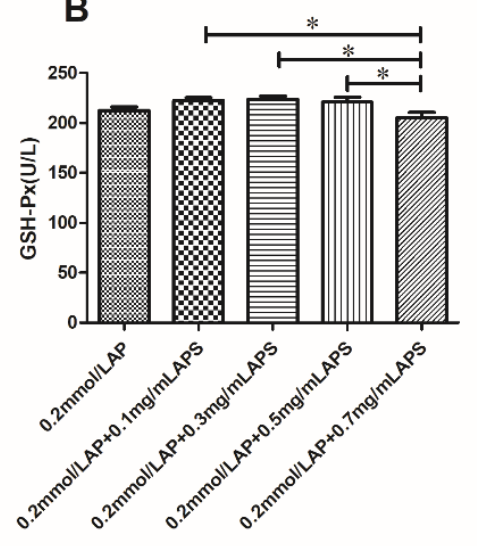

C

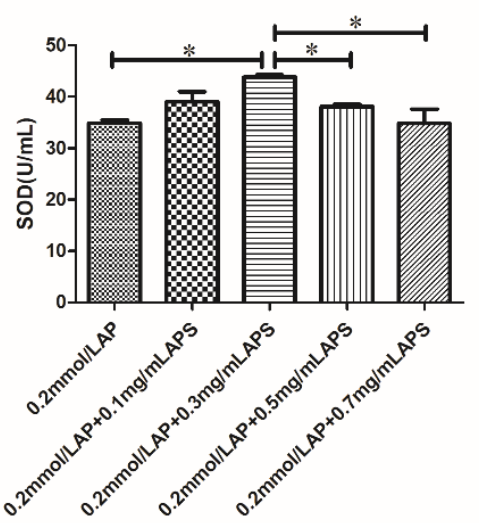

Figure 11. Effect of $0.2 \mathrm{mmol} / \mathrm{L} \mathrm{AP} \mathrm{combined} \mathrm{with} \mathrm{each} \mathrm{concentration} \mathrm{of} \mathrm{APS} \mathrm{on} \mathrm{the} \mathrm{antioxidant} \mathrm{enzyme} \mathrm{activity} \mathrm{after}$ thawing of bovine semen $(\mathbf{A}-\mathbf{C})$. The different asterisks represent significant differences among the groups $\left({ }^{*} p<0.05\right)$.

\subsubsection{Effect of the Combined Use of AP and APS on ROS and MDA Levels}

The combination of AP and APS further reduced both the ROS and MDA levels in frozen semen samples compared to $0.2 \mathrm{mmol} / \mathrm{L} \mathrm{AP}$ alone (Figure 12), and a combination of $0.2 \mathrm{mmol} / \mathrm{L} \mathrm{AP}$ and $0.3 \mathrm{mg} / \mathrm{mL}$ APS significantly reduced the ROS and MDA levels in these semen samples $(p<0.05)$. 

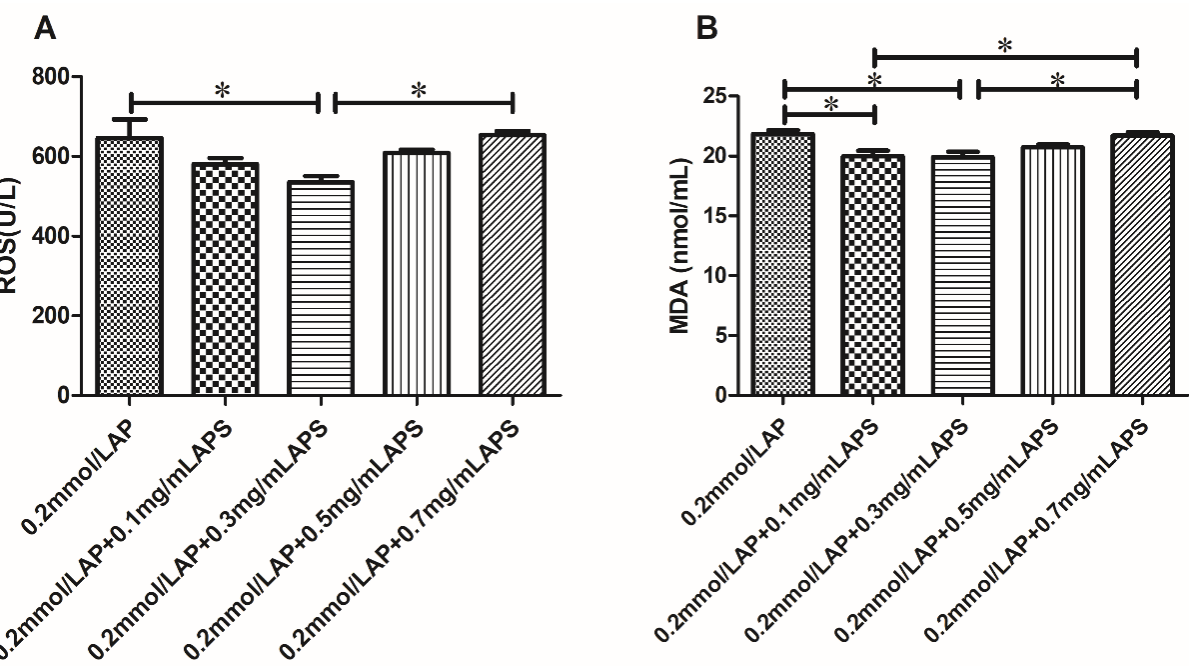

Figure 12. Effect of AP and APS on the oxidation products of cattle semen when used in combination $(\mathbf{A}, \mathbf{B})$. The different asterisks represent significant differences among the groups $\left({ }^{*} p<0.05\right)$.

\section{Discussion}

As oxidative stress affects the quality of frozen semen, adding antioxidants has become the main method used to improve sperm quality after thawing. Our results show that adding AP and APS could improve the quality of frozen semen. AP and APS were added in combination, and the quality of semen was further improved, compared to when they were added separately.

Bacterial contamination is one of the main factors causing the quality of frozen semen to decline. Recent research has shown that AP has antibacterial, antiviral, antifungal, and antiparasitic properties [25]. Consistent with the results of this study, we found that AP could reduce bacterial contamination and improve the kinematic parameters and abnormal semen movement in frozen semen. MDA is the final product of LPO. Low levels of MDA can improve the quality of frozen semen. A recent study found that AP could increase the CAT content in pig semen and reduce MDA levels [2]. In this study, it was found that adding AP could improve the CAT in frozen bovine semen and contribute to reducing the content of MDA. Overproduction of ROS can cause oxidative stress. Research shows that apigenin can show the chemopreventive potential of cancer cells by regulating the intracellular accumulation of ROS in lung cancer cells and the expression of antioxidant enzymes [26]. In this study, it was found that AP could reduce the ROS content in frozen semen and increase the expression of various antioxidant enzymes. It was also observed in previous studies that treatment with AP attenuated the reduction in superoxide dismutase activity and glutathione levels and reduced the levels of reactive oxygen species and malondialdehyde in rat hepatic stellate cells [27]. These findings are similar to the results of this study. Oxidative stress can cause sperm motility to decrease after thawing. An increasing number of studies have shown that the imbalance between the production of ROS and the level of antioxidants in sperm is the main cause of oxidative stress. As the main source of ROS is the mitochondria, mitochondrial damage caused by oxidative stress will lead to changes in the level of ROS in sperm, leading to the loss of sperm motility after thawing [28]. Mitochondria are the main energy supply sites for cells. Recent studies have found that, compared to the control group, adding APS to semen diluent can significantly increase the mitochondrial membrane potential of boar semen and reduce the level of ROS and malondialdehyde content [18]. In this study, it was found that the mitochondrial integrity of frozen semen was improved after the addition of APS, and the MDA and ROS levels were reduced. Previous research found that another way for sperm to gain energy in a diluted solution is through glycolysis. APS can provide energy for sperm in this way. It protects the mitochondria by removing reactive oxygen species and increasing the antioxidant capacity, and ultimately improves sperm energy metabolism [19]. Our results 
observed that the content of antioxidant enzymes such as SOD in thawed semen has been improved by the addition of APS. This result may be due to astragalus polysaccharides protecting the mitochondria of semen and improving the energy metabolism of semen. In some studies, it was found that APS could protect cells by improving cell viability, reducing apoptosis, and inhibiting the production of inflammatory cytokines [29]. APS has a protective effect on cells and can inhibit inflammatory cytokines, but its protective effect on bovine semen is unknown. It was observed that after thawing, compared to the control group, the group with APS added exhibited an increase in the vitality of sperm. Some studies have shown that APS can reduce the expression of Aspergillus toxin A, promoting apoptosis-related proteins and pro-inflammatory cytokines [30]. APS can reduce the expression of pro-inflammatory cytokines, and we found that APS can improve the inflammatory damage caused during freezing and thawing. Through observation under a microscope sperm analyzer, it was found that the multiple kinematic parameters of sperm were improved compared to the control group. The circle movement was also relieved. In some studies, APS provided effective protection in various disease models related to oxidative stress for heart, brain, kidney, intestine, liver, and lung damage [31]. A previous study showed that the use of APS in vitro can enhance sperm motility and improve testicular toxicity and has proven its potential to treat male infertility [32]. APS can not only improve the quality of semen but also has great potential in the treatment of infertility. Similar to previous studies, it was found that the addition of APS could increase the acrosome and plasma membrane integrity and other indicators of semen by adjusting the content of various antioxidant enzymes in frozen semen.

Some studies have shown that different antioxidants have a synergistic effect on the removal of active oxygen. This is because they have different binding speeds with active free radicals and different ways of action [33]. Due to the different stability that results from a combination of antioxidants, the synergistic effect of two different antioxidants can further improve the various indices of semen after thawing compared to the addition of a single antioxidant alone. As expected, our study found that combined addition of antioxidants significantly improved the quality of semen compared to a single addition, and the index with no significant difference was also improved compared to a single addition. This result confirms the feasibility of adding antioxidants in combination. In some studies, a combination of curcumin and dithioerythritol can improve the integrity of semen plasma membrane and increase the expression of glutathione peroxidase [34]. It has also been found in recent studies that, $\mathrm{AP}$, as a ketone antioxidant similar to curcumin, can be used in combination with ferulic acid to improve the quality of pig semen. APS is a plant polysaccharide that is mild and non-irritating. Some studies have shown that the combined use of APS and polysaccharide peptides can immunosuppress and immunomodulate lung cancer in mice [35], resulting in low toxicity and no mutagenesis. Upon combining AP and APS, it was observed that the combination of the two antioxidants could improve the quality of semen without other side effects. DNA integrity was vital for evaluating the spermatozoa quality. Assessing the integrity of DNA is valuable for the identification of seriously damaged spermatozoa. Our experiment was mainly focus on evaluating the effects of two antioxidants on sperm motility, kinematic parameters, and various antioxidant enzyme indexes after freezing and thawing. Therefore we ignored the assessment of DNA integrity and we did not detect DNA integrity. Ignoring the detection of this intrinsic indicator is also a limitation of this experiment. In addition, adding these substances could improve the vitality after freezing; however, this does not imply that they can improve the fertilization ability, because there is no measurement of the conception rate or other indicators, which is a limitation of this research.

\section{Conclusions}

In conclusion, adding AP and APS alone could significantly improve the kinematic parameters of sperm, acrosome integrity, plasma membrane integrity, and mitochondrial activity. However, a combined addition could further improve the kinematic parameters of 
sperm, the integrity of the acrosome, plasma membrane, and mitochondria. These results may be due to the addition of AP and APS alleviating the level of ROS and MDA as well as increasing the enzymatic activity of CAT, SOD, and GSH-Px.

Author Contributions: Conceptualization, H.W. and P.L.; methodology, H.W.; software, H.W.; validation, H.W., W.L. and J.W.; formal analysis, H.L.; investigation, H.W.; resources, W.L.; data curation, H.W.; writing—original draft preparation, H.W..; writing—review and editing, J.W.; visualization, J.Z.; supervision, C.Y.; project administration, J.W.; funding acquisition, W.L. All authors have read and agreed to the published version of the manuscript.

Funding: This research received no external funding.

Institutional Review Board Statement: The study was conducted according to the guidelines of the Declaration of Helsinki, and approved by Ethics Committee of Jilin Agricultural University (20200803001; 3 August 2020).

Acknowledgments: This work was supported by the National Key Research and Development Program of China (Grant Number: 2018YFE0122000); Jilin province science and technology development plan item (20200301031RQ).

Conflicts of Interest: The authors declare no conflict of interest.

\section{References}

1. Buranaamnuay, K.; Tummaruk, P.; Singlor, J.; Rodriguez-Martinez, H.; Techakumphu, M. Effects of straw volume and Equex-STM on boar sperm quality after cryopreservation. Reprod. Domest. Anim. 2009, 44, 69-73. [CrossRef] [PubMed]

2. Pei, Y.; Yang, L.; Wu, L.; He, H.; Geng, G.; Xu, D.; Chen, H.; Li, Q. Combined effect of apigenin and ferulic acid on frozen-thawed boar sperm quality. Anim. Sci. J. 2018, 89, 956-965. [CrossRef] [PubMed]

3. Layek, S.S.; Mohanty, T.K.; Kumaresan, A.; Parks, J.E. Cryopreservation of bull semen: Evolution from egg yolk based to soybean based extenders. Anim. Reprod. Sci. 2016, 172, 1-9. [CrossRef] [PubMed]

4. de Lamirande, E.; Gagnon, C. Reactive oxygen species and human spermatozoa. I. Effects on the motility of intact spermatozoa and on sperm axonemes. J. Androl. 1992, 13, 368-378.

5. Bilodeau, J.F.; Blanchette, S.; Gagnon, C.; Sirard, M.A. Thiols prevent H2O2-mediated loss of sperm motility in cryopreserved bull semen. Theriogenology 2001, 56, 275-286. [CrossRef]

6. Aurich, J.E.; Schonherr, U.; Hoppe, H.; Aurich, C. Effects of antioxidants on motility and membrane integrity of chilled-stored stallion semen. Theriogenology 1997, 48, 185-192. [CrossRef]

7. Son, M.; Lee, M.; Sung, G.H.; Lee, T.; Shin, Y.S.; Cho, H.; Lieberman, P.M.; Kang, H. Bioactive activities of natural products against herpesvirus infection. J. Microbiol. 2013, 51,545-551. [CrossRef]

8. Patel, D.; Shukla, S.; Gupta, S. Apigenin and cancer chemoprevention: Progress, potential and promise (review). Int. J. Oncol. 2007, 30, 233-245. [CrossRef]

9. Miccadei, S.; di Venere, D.; Cardinali, A.; Romano, F.; Durazzo, A.; Foddai, M.S.; Fraioli, R.; Mobarhan, S.; Maiani, G. Antioxidative and apoptotic properties of polyphenolic extracts from edible part of artichoke (Cynara scolymus L.) on cultured rat hepatocytes and on human hepatoma cells. Nutr. Cancer 2008, 60, 276-283. [CrossRef]

10. Tang, D.; Chen, K.; Huang, L.; Li, J. Pharmacokinetic properties and drug interactions of apigenin, a natural flavone. Expert Opin. Drug Metab. Toxicol. 2017, 13, 323-330. [CrossRef]

11. Shukla, S.; Gupta, S. Apigenin: A promising molecule for cancer prevention. Pharm. Res. 2010, 27, 962-978. [CrossRef]

12. Li, F.; Lang, F.; Zhang, H.; Xu, L.; Wang, Y.; Zhai, C.; Hao, E. Apigenin Alleviates Endotoxin-Induced Myocardial Toxicity by Modulating Inflammation, Oxidative Stress, and Autophagy. Oxidative Med. Cell. Longev. 2017, 2017, 2302896. [CrossRef] [PubMed]

13. Lin, B.W.; Gong, C.C.; Song, H.F.; Cui, Y.Y. Effects of anthocyanins on the prevention and treatment of cancer. Br. J. Pharmacol. 2017, 174, 1226-1243. [CrossRef]

14. Nafisi, S.; Hashemi, M.; Rajabi, M.; Tajmir-Riahi, H.A. DNA adducts with antioxidant flavonoids: Morin, apigenin, and naringin. DNA Cell Biol. 2008, 27, 433-442. [CrossRef] [PubMed]

15. Miller, L.G. Herbal medicinals: Selected clinical considerations focusing on known or potential drug-herb interactions. Arch. Intern. Med. 1998, 158, 2200-2211. [CrossRef] [PubMed]

16. Weng, X.G.; Cai, M.M.; Zhang, Y.T.; Liu, Y.; Gao, Z.L.; Song, J.; Liu, Z.H. Effect of Astragalus polysaccharide addition to thawed boar sperm on in vitro fertilization and embryo development. Theriogenology 2018, 121, 21-26. [CrossRef]

17. Fu, J.; Yang, Q.; Li, Y.; Li, P.; Wang, L.; Li, X. A mechanism by which Astragalus polysaccharide protects against ROS toxicity through inhibiting the protein dephosphorylation of boar sperm preserved at 4 degrees C. J. Cell Physiol. 2018, 233, 5267-5280. [CrossRef]

18. Mosca, F.; Zaniboni, L.; Abdel, S.A.; Madeddu, M.; Iaffaldano, N.; Cerolini, S. Effect of dimethylacetamide and N-methylacetamide on the quality and fertility of frozen/thawed chicken semen. Poult. Sci. 2019, 98, 6071-6077. [CrossRef] 
19. Mizutani, T.; Sumigama, S.; Nagakubo, K.; Shimizu, N.; Oba, H.; Hori, T.; Tsutsui, T. Usefulness of addition of Orvus ES paste and sodium lauryl sulfate to frozen feline semen. J. Vet. Med. Sci. 2010, 72, 23-27. [CrossRef]

20. Shi, X.R.; Liu, S.Y.; Chen, Y.; Li, F.L.; Xue, H.L.; Dang, Y.H.; Li, Z.L. Apigenin affects semen parameters in male mice. Natl. J. Androl. 2010, 16, 778-782.

21. Tarig, A.A.; Wahid, H.; Rosnina, Y.; Yimer, N.; Goh, Y.M.; Baiee, F.H.; Khumran, A.M.; Salman, H.; Ebrahimi, M. Effect of different concentrations of egg yolk and virgin coconut oil in Tris-based extenders on chilled and frozen-thawed bull semen. Anim. Reprod. Sci. 2017, 182, 21-27. [CrossRef] [PubMed]

22. Masoudi, R.; Sharafi, M.; Zare, S.A.; Towhidi, A.; Kohram, H.; Zhandi, M.; Esmaeili, V.; Shahverdi, A. Effect of dietary fish oil supplementation on ram semen freeze ability and fertility using soybean lecithin- and egg yolk-based extenders. Theriogenology 2016, 86, 1583-1588. [CrossRef] [PubMed]

23. Harrison, R.A.; Vickers, S.E. Use of fluorescent probes to assess membrane integrity in mammalian spermatozoa. J. Reprod. Fertil. 1990, 88, 343-352. [CrossRef] [PubMed]

24. Shahverdi, A.; Sharafi, M.; Gourabi, H.; Yekta, A.A.; Esmaeili, V.; Sharbatoghli, M.; Janzamin, E.; Hajnasrollahi, M.; Mostafayi, F. Fertility and flow cytometric evaluations of frozen-thawed rooster semen in cryopreservation medium containing low-density lipoprotein. Theriogenology 2015, 83, 78-85. [CrossRef]

25. Wang, M.; Firrman, J.; Liu, L.; Yam, K. A Review on Flavonoid Apigenin: Dietary Intake, ADME, Antimicrobial Effects, and Interactions with Human Gut Microbiota. BioMed Res. Int. 2019, 2019, 7010467. [CrossRef]

26. Imran, M.; Aslam, G.T.; Atif, M.; Shahbaz, M.; Batool, Q.T.; Hanif, M.M.; Salehi, B.; Martorell, M.; Sharifi-Rad, J. Apigenin as an anticancer agent. Phytother. Res. 2020, 34, 1812-1828. [CrossRef]

27. Pan, X.; Shao, Y.; Wang, F.; Cai, Z.; Liu, S.; Xi, J.; He, R.; Zhao, Y.; Zhuang, R. Protective effect of apigenin magnesium complex on $\mathrm{H}_{2} \mathrm{O}_{2}$-induced oxidative stress and inflammatory responses in rat hepatic stellate cells. Pharm. Biol. 2020, 58, 553-560. [CrossRef]

28. Sikka, S.C. Relative impact of oxidative stress on male reproductive function. Curr. Med. Chem. 2001, 8, 851-862. [CrossRef]

29. Ren, Q.; Zhao, S.; Ren, C.; Ma, Z. Astragalus polysaccharide alleviates LPS-induced inflammation injury by regulating miR-127 in H9c2 cardiomyoblasts. Int. J. Immunopathol. Pharmacol. 2018, 32, 2058738418759180. [CrossRef]

30. Liu, D.; Su, J.; Lin, J.; Qian, G.; Chen, X.; Song, S.; Huang, K. Activation of AMPK-dependent SIRT-1 by astragalus polysaccharide protects against ochratoxin A-induced immune stress in vitro and in vivo. Int. J. Biol. Macromol. 2018, 120, 683-692. [CrossRef]

31. Shahzad, M.; Shabbir, A.; Wojcikowski, K.; Wohlmuth, H.; Gobe, G.C. The Antioxidant Effects of Radix Astragali (Astragalus membranaceus and Related Species) in Protecting Tissues from Injury and Disease. Curr. Drug Targets 2016, 17, $1331-1340$. [CrossRef] [PubMed]

32. Kim, W.; Kim, D.R.; Chang, M.S.; Park, S.K. Astragalus membranaceus augment sperm parameters in male mice associated with cAMP-responsive element modulator and activator of CREM in testis. J. Tradit. Complement. Med. 2016, 6, 294-298. [CrossRef] [PubMed]

33. Ren, F.; Feng, T.; Dai, G.; Wang, Y.; Zhu, H.; Hu, J. Lycopene and alpha-lipoic acid improve semen antioxidant enzymes activity and cashmere goat sperm function after cryopreservation. Cryobiology 2018, 84, 27-32. [CrossRef] [PubMed]

34. Bucak, M.N.; Baspinar, N.; Tuncer, P.B.; Coyan, K.; Sariozkan, S.; Akalin, P.P.; Buyukleblebici, S.; Kucukgunay, S. Effects of curcumin and dithioerythritol on frozen-thawed bovine semen. Andrologia 2012, 44, 102-109. [CrossRef] [PubMed]

35. Zhou, X.; Liu, Z.; Long, T.; Zhou, L.; Bao, Y. Immunomodulatory effects of herbal formula of astragalus polysaccharide (APS) and polysaccharopeptide (PSP) in mice with lung cancer. Int. J. Biol. Macromol. 2018, 106, 596-601. [CrossRef] [PubMed] 